Bangladesh J. Plant Taxon. 25(1): 113-117, 2018 (June)

(C) 2018 Bangladesh Association of Plant Taxonomists

\title{
PETROSAVIACEAE, A NEW FAMILY RECORD FOR INDIA
}

\author{
Nazir Ahmad Bhat, Licha Jeri ${ }^{1}$, Dilip KR. Roy ${ }^{2}$ AND Yogendra Kumar \\ Centre for Advanced Studies in Botany, North Eastern Hill University, \\ Shillong -793022, Meghalaya, India
}

Keywords: Petrosaviaceae; Arunachal Pradesh; Petrosavia sakuraii; India; New Record.

The family Petrosaviaceae Hutch. contains two genera, namely Japonolirion Nakai and Petrosavia Beccari distributed from Japan and China through southeastern Asia to Borneo (Cameron et al., 2003; Tobe and Takahashi, 2009; Remizowa et al., 2017). The genus Petrosavia, containing two presently known species namely P. sakuraii (Makino) J.J. Sm. ex van Steenis and $P$. stellaris Beccari, and Japonolirion Nakai is a monotypic genus with J. osense Nakai (Ohashi, 2000; Cameron et al., 2003; Tobe and Takahashi, 2009; Remizowa et al., 2017). The species $P$. sakuraii was described in 1903 as Miyoshia sakuraii by Makino from Japan (Makino, 1903) and later Smith (1934) made the new combination. It occurs on the forest floor of broad-leaved or coniferous trees (Takahashi et al., 1993) and is distributed in humid temperate regions of Japan, southern China, Taiwan, Myanmar, northern Thailand, Vietnam and Indonesia (Remizowa et al., 2017). $P$. sakuraii differs from its congener $P$. stellaris in having racemose inflorescence (vs. umbel or corymbose), capsule with rounded and moderately recurved carpels (vs. laterally flattened and strongly recurved carpels) (Remizowa et al., 2017).

While studying the floristic account of Talle Valley Wildlife Sanctuary of Arunachal Pradesh, the authors collected some interesting specimens of a small yellow saprophytic plant growing on the decaying leaf litter, under the canopy of dense evergreen forests. After a critical examination of the specimens, consultation of relevant literature (Takahashi et al., 1993; Ohashi, 2000; Cameron et al., 2003; Remizowa et al., 2017) and expert scrutiny, its identity was confirmed as Petrosavia sakuraii (Makino) J.J. Sm. ex van Steenis. A scrutiny of literature pertaining to the flora of India (Karthikeyan, 2000, 2009) revealed that the family Petrosaviaceae is hitherto not reported from India. Therefore, the present report of this taxon from Arunachal Pradesh is the first report of the species, genus and family for India. The taxonomic description along with illustration and photographs of this taxon is provided to facilitate easy identification in the field.

Petrosavia sakuraii (Makino) J.J. Smith ex van Steenis, Trop. Natur. 23: 52 (1934); Masamune, Trans. Nat. Soc. Form 28: 48(1938); Ohba, J. Jap. Bot. 59: 108(1984); Ohashi, Taiwania 45: 266 (2000); Remizowa et al., Nor. J. Bot. 35: 264 (2017). Miyoshia sakuraii Makino, Bot. Mag. (Tokyo) 17: 145 (1903).

(Figs $1 \& 2$ ).

Type: Japan. Mino: foot of Mt Ena, shady forests, 27 Jul 1903, H. Sakurai, s.n. (Holotype \& Isotype: MAK!).

Synonyms: Petrosavia sinii (K. Krause) Gagnep., Fl. Indo-Chine 6: 802 (1934). Miyoshia sinii (K. Krause) Nakai, J. Jap. Bot. 17(4): 191 (1941).

Type: China. Guangxi: Yao shan, in a bamboo thicket, $3000 \mathrm{ft}, 6$ June 1928, S.S. Sin and K.K. Whang 421 (Holotype: B!).

\footnotetext{
${ }^{1}$ Corresponding author. Email: lichajeri2013@gmail.com

${ }^{2}$ Botanical Survey of India, Eastern Regional Centre, Shillong-793023, Meghalaya, India.
} 
Mycoheterotrophic, achlorophyllous, tough, pale yellow, glabrous herbs, 11-28 cm tall. Rhizome slender, covered with numerous minute membranaceous scales; scales 1-nerved, entire, lanceolate-ovate, apex acuminate-obtuse, c. $3 \mathrm{~mm}$ long. Stem erect, 1-2 arising from the rhizome, glabrous. Leaves reduced to scales, alternate, $2-3 \mathrm{~cm}$ apart, sessile, simple, margin entire, membranaceous, 1-nerved, lanceolate, 2-4 mm long. Inflorescence terminal, racemose, 3-15flowered. Flower erect, creamy or whitish, bisexual, 3-5 $\mathrm{mm}$ in diam.; bract usually longer or equal to pedicels in young flowers but shorter in fruits due to elongation of pedicel, subulate, entire, membranaceous, apex acuminate, 1-2 mm long; bracteole 1, near the centre or base of the pedicel; pedicel erect, ascending, slightly shorter than flower, 2-5 mm long, flowers sometimes paired in the lower part of the raceme. Perianth funnel-shaped; outer tepals 3 , much smaller and

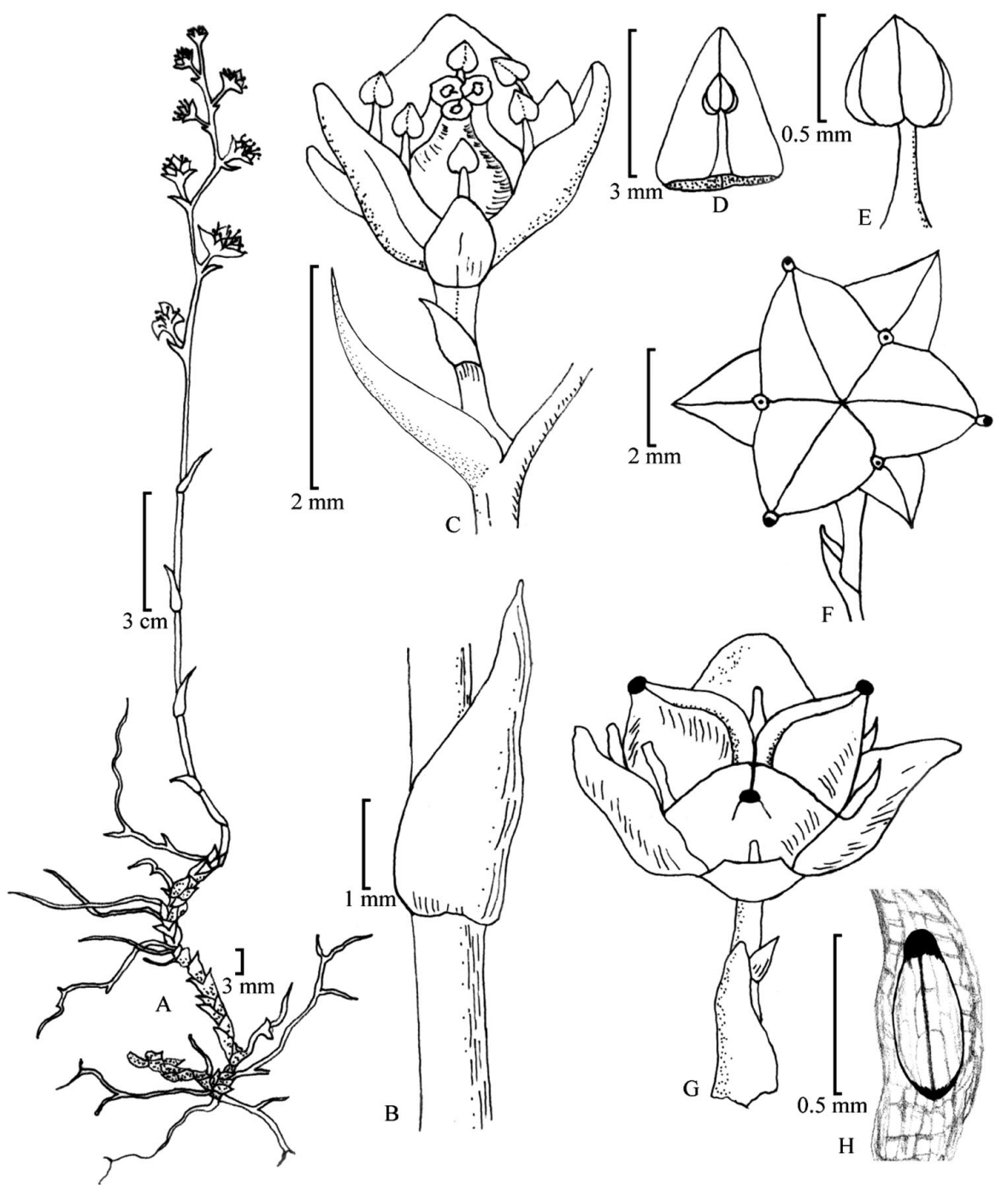

Fig. 1. Petrosavia sakuraii (Makino) J.J. Smith ex van Steenis: A. Habit; B. A portion of stem with scale;

C. Flower; D. Inner tepal with stamen; E. Stamen; F\&G. Capsule front and side view; H. Seed. 


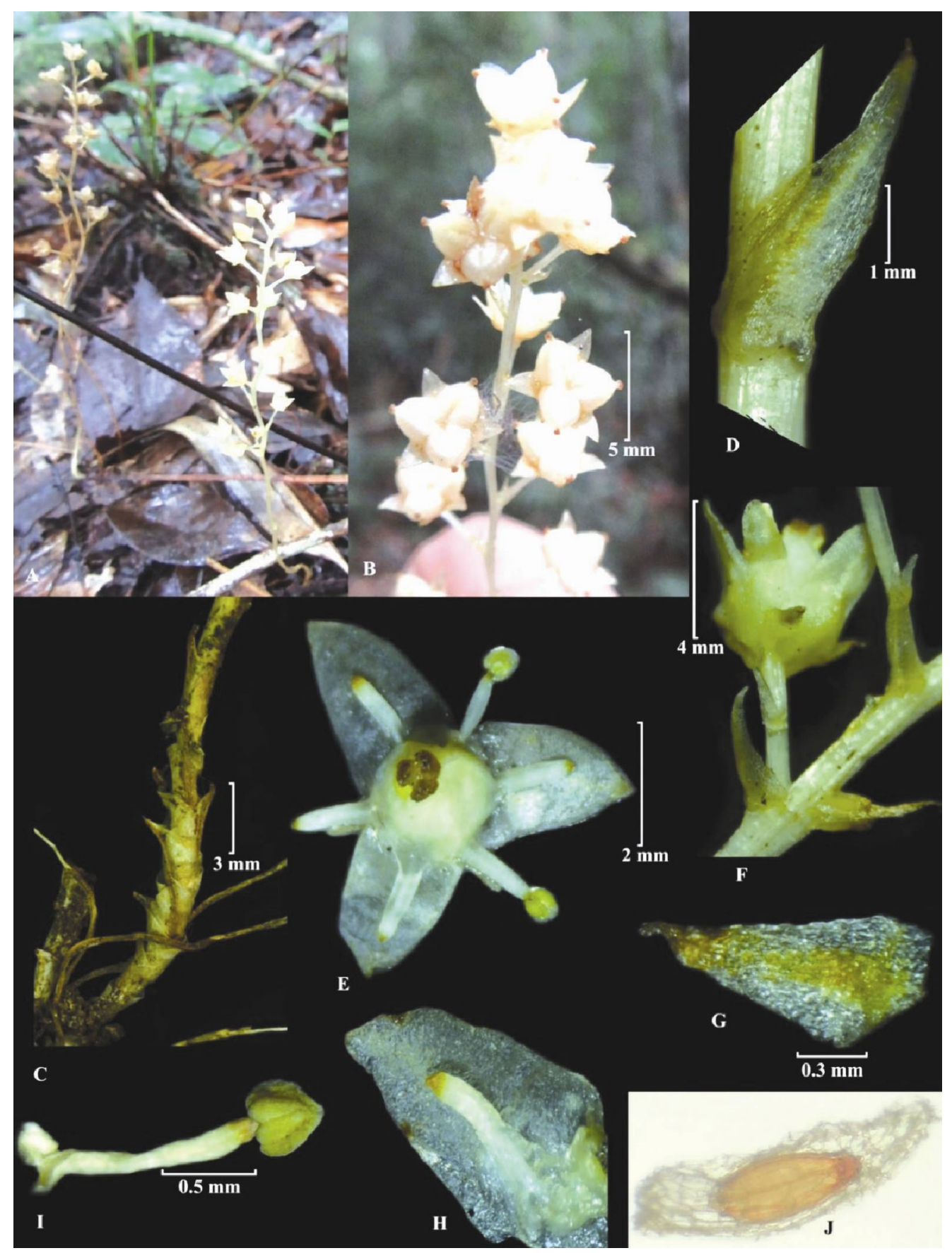

Fig. 2. Petrosavia sakuraii (Makino) J.J. Smith ex van Steenis: A. Habit; B. Inflorescence; C. Rhizome; D. A portion of stem with scale; E. Flower - front side; F. Flower - side view with bract; G. Outer tepal; H. Inner tepal with stamen; I. Stamen; J. Seed. 
narrow than the inner, deltoid-ovate, apex acute, c. $1 \mathrm{~mm}$ long; inner tepals 3, ovate, spreading, alternate with outer tepals, obtuse-submucronate at the apex, 1.5-2.0 mm long. Stamens 6, shorter than the inner tepal, c. $1.5 \mathrm{~mm}$ long; filament subulate; anthers ovate, minute, auriculate at base, dorsifixed, introrse. Ovary semi-inferior, 3-locular in the syncarpous region; carpels 3, erect, connate at base and free above the tepal, conical short; style 1 on each carpel, erect, c. $1 \mathrm{~mm}$ long; stigma depressed to sub-capitate; ovules numerous. Capsule recurved, dehiscing along the adaxial side, c. $3 \mathrm{~mm}$ in diam. Seeds elliptical to oblong, numerous, small, hyaline wings around the seed body, $0.5-0.8 \times 0.2-0.4 \mathrm{~mm}$.

Flowering and Fruiting: August to September.

Habitat: P. sakuraii grows mainly on thick, shady moist places of the virgin forests. The species normally grows terrestrial in the decomposed litter but some individuals have been collected from mossy trees as an epiphyte. The exact growing conditions were not specified but it is possible that they grow as a low-level epiphyte in a humid environment.

Specimen examined: India: Arunachal Pradesh: Lower Subansiri district, Talle Valley Wildlife Sanctuary, alt. $2012 \mathrm{~m}, 2^{\circ} 32.977^{\prime} \mathrm{N}, 9^{\circ} 54.395^{\prime} \mathrm{E}, 13$ August 2017, N.A. Bhat \& Licha Jeri 702 (ASSAM!).

Distribution: India (Arunachal Pradesh), Vietnam, Japan, southern China, Taiwan, Myanmar, northern Thailand and Indonesia (northern half of Sumatra).

Conservation status: The population size of the species in the studied site was very low and facing a number of anthropogenic threats. The major threat operating in the area of its occurrence is unsustainable harvesting of orchids and medicinal plants (Panax pseudoginseng Wall., Paris polyphylla Sm. and Illicium griffithii Hook.f. \& Thomson) for commercial purposes. In order to conserve this extremely rare species from extinction, immediate conservative strategies are needed. Along with checking of illegal harvesting, the habitat of the species needs to be strictly protected. As the species have mycoheterotrophic nature, hence is very difficult to cultivate. However, its capacity is to produce large numbers of seeds, therefore scientific methods like 'in situ' seed sowing would be the hopeful method to restore the population of the species. It has been provisionally listed as a Data Deficient (DD) as per IUCN guidelines until the populations can be evaluated.

\section{Acknowledgements}

The authors are thankful to the State Forest Department, Arunachal Pradesh for permitting us to work in the Wildlife Sanctuary. The author (LJ) is thankful to the University Grant Commission (UGC), New Delhi for the financial support through Maulana Azad National Fellowship (MANF2014-15-CHR-ARU-35998). We are also grateful to Head of Office, Botanical Survey of India, Eastern Regional Centre, Shillong for allowing us to consult the herbarium. We are cordially grateful to Mr. H. Choudhury, for assisting us in illustrations and the help and cooperation received from the local people is also acknowledged.

\section{References}

Cameron, K.M., Chase, M.W. and Rudall, P.J. 2003. Recircumscription of the monocotyledonous family Petrosaviaceae to include Japonolirion. Brittonia 55: 214-255.

Karthikeyan, S. 2000. A statistical analysis of flowering plants of India. In: Singh, N.P., Singh, D.K., Hajra, P.K. and Sharma, B.D. (Eds), Flora of India. Introductory Vol. Part II. Botanical Survey of India, Calcutta, pp. 201-217.

Karthikeyan, S. 2009. Flowering plants of India in 19th and 21st centuries - A comparison. In: Krishnan, S. and Bhat, D.J. (Eds), Plant and Fungal Biodiversity and Bioprospecting. Goa University, Goa, pp. 19-29. 
Makino, T. 1903. Observation on the flora of Japan. Bot. Mag. (Tokyo) 17: 145-146.

Ohashi, H. 2000. Petrosavia (Petrosaviaceae) in Taiwan and Hainan. Taiwania 45: 263-269.

Remizowa, M.V., Nuraliev, M.S., Averyanov, L.V., Kuznetsov, A.N. and Kuznetsova, S.P. 2017. A revision of the family Petrosaviaceae in Vietnam. Nord. J. Bot. 35: 262-271.

Smith, J.J. 1934. Melanthiaceae Petrosavia sakuraii (Makino) J.J. Sm. ex Steenis. Trop. Nat. 23 : 52.

Takahashi, H., Nishio, E. and Hayashi, H. 1993. Pollination biology of the saprophytic species Petrosavia sakuraii (Makino) van Steenis in central Japan. J. Plant Res. 106: 213-217.

Tobe, H. and Takahashi, H. 2009. Embryology of Petrosavia (Petrosaviaceae, Petrosaviales): evidence for the distinctness of the family from other monocots. J. Plant Res. 122: 597-610.

(Manuscript received on 17 October 2017; revised on 24 March 2018) 